\title{
Ict - A Sustainable Strategy for Women Empowerment in Kerala
}

\author{
Vijesh Venugopal \\ Asst.Professor of Commerce Post Graduate Department of Commerce \& Management Studies \\ N.S.S College Nemmara - Palakkad Kerala - 678508
}

\begin{abstract}
The major players in IT industry are now offering an environment that will retain the talented women workforce. To develop women friendly work environment leading companies are now offering benefits like lactation centers, extra maternity leave, work from home policies, crèches, and option to relocate to city of their choice in case of transfer of the husband. Educated Women have had significant breakthrough by breaking the traditional household, child rearing, socially oppressed life style, because of access to IT. It really requires an innovative strategy to create large-scale employment. Though late, the government has now realized that ICT can play an important role in generating large-scale employment opportunities, suitable to the educated unemployed in Kerala. IT provides an enabling potential to improve women's lives. It can provide an important tool in meeting women's basic needs and can provide access to resources to lead women out of poverty. Here is the relevance of the present study.

Key words: Information and Communication Technology, Women Empowerment, Digital Divide, Gender Divide, Akshaya programme,
\end{abstract}

\section{Introduction}

India has become a dominant player in the information technology industry globally. In the past decades industrial scenario in India was dominated by agriculture and manufacturing sector growth. But in the last 10 years especially after 1995 information technology industry has started contributing significantly in economic growth of India. Information Technology now is a robust industry worth $\$ 60$ billion. Information Technology industry is unique with regard to participation of women in the workforce. Every second fresh recruit in IT industry now is a woman. E-governance initiative of government has also opened an opportunity for women empowerment by increasing access to information for women. IT provides access to same information to women as it is available to men. This information flow is uncensored and without any distortions. IT reduces the impact of barriers of time and distance in organizing and managing the service delivery of businesses. A large part of jobs outsourced are going to women. The freedom to work from anywhere and anytime can become a catalyst for financial independence and empowerment of women by enhancing their extra income.

\section{The Ict Concept}

Information Communication Technologies (ICT) consists of computer hardware, Software, Internet and other communication networks, and media used to collect, store, process and transmit information in the form of voice, text, data and images. In short, ICT deals with the use of electronic computers and computer software to convert, store, protect, process, transmit and retrieve information. ICT revolution is the result of integration of computer technology and communication technology. ICT industry includes all companies that are engaged in production and marketing of hardware, software, services and networking. ICT offers flexibility of time and space. These attributes make ICT a valuable resource for women especially in developing countries who suffer from limited availability of time, social isolation, and lack of access to knowledge and productive resources. However, there are two major areas of concern that have emerged due to variation in production and consumption of ICT in different countries. They are the Digital Divide and the Gender Divide. The term digital divide refers to those who can benefit from ICT, and those who don't. Also, gender-based inequalities limit how women can benefit from the opportunities offered by Information and Communication Technologies (ICTs) and how they can influence the developing global knowledge economy, creating a gender divide. The imbalances between women's and men's access to and participation in ICT and asserts that more needs to be done to ensure that women equally enjoys the benefits arising from global knowledge based economy at all levels of ICT policy and practice.

The support of women's entrepreneurial activities is an important benefit of ICT, which has not been realized properly in many developing countries. However, there are isolated experiences where ICT is judiciously utilized for the economic empowerment of poor women. Such experiences need detailed documentation and analysis to identify key barriers to women's participation in ICT as well as some innovative areas where women can participate in ICT revolution. Women and girls are exposed to great discrimination in economic, education, health and social services access worldwide. On the other hand the range of 
women's economic activities in developing countries is very broad. It includes formal sector and informal sector employment, as well as self-employment in farming, trading and crafts production etc. There are numerous possibilities for ICTs to improve women's economic activities in the field of trade, governance, education, health, crafts, employment in formal as well as informal sector. ICT's bring lot of opportunities to women in the work situations and small business. Teleporting, flexi time and work from home arrangements are some of the gender dimensions of ICT's usages. Keeping these facts in mind, the proposed study identified the needs of infrastructure and policy intervention to make ICT sector to contribute towards enhancing empowerment of women in India.

\section{Significance Of The Study}

A large group of working women of India is in the rural and unorganized sectors. Socially majority of rural women are still traditionally bound and are in disadvantageous position. Globalisation is opening up the Indian economy at a very high speed. During the past decades, advances in information technology have facilitated a global communication network that transcends national boundaries and has an impact on public policy, private attitudes and behaviours, especially of children and young adults. Everywhere the potential exists for the information technology to make a far greater contribution to the advancement of rural women.

In Kerala the relevance of empowering women is also more important. As per the 2001 census, it counted 16.36 million females against total population of 31.83 million in which 12.12 million women live in rural area and 30 per cent of the rural women live below poverty line. The World Summit on Information Society (WISS) in 2003 affirms that despite of significant regional variations, ICT development affects women and men differently and in all regions women face fundamental barriers to benefiting from ICT as well as influencing ICT development policies. The report highlights the imbalance between women's and men's access to and participation in ICT and asserts that more needs to be done to ensure that women equally enjoy the benefit arising from global knowledge.

IT provides an enabling potential to improve women's lives. It can provide an important tool in meeting women's basic needs and can provide access to resources to lead women out of poverty. Against this background, this study focuses on the importance of IT, for reducing poverty and economic empowerment of rural women in Kerala. It also assesses the internet connectivity in Kerala and investigates infrastructure issues that impede the access by women to IT.

\section{Review Of Literature}

In this area, a brief appraisal of the studies on the issues surrounding women employed in IT industry, their empowerment, agency, the patrifocal gender norms of Kerala women as well as the constraints and coping strategies employed by them to achieve work life balance is presented with a view to unveil what has already been done on the issues related to the theme of the present study.

Panicker and Soman (1984) states that by all indicators, the quality of life of women and children in Kerala compares favourably with that of their counterparts in other states of the Indian union. This is especially true in terms of survival norms, access to education, medical care and other public services, irrespective of the level of income and socio-economic status. Kerala society had been mainly patriarchal and patrifocal which denies egalitarian gender relations. Patrifocality is characterized by: subordination of individual interests to the welfare of the family; gender differentiated family roles with females being associated with the private sphere; gender differentiated family authority structure(with authority of same generational males over socially equivalent females, such as husbands over wives, brothers over sisters); family control of marriage arrangements; patrilineal descent, inheritance and succession; patrifocal residence, with daughters shifting allegiance to husband's family after marriage; and an ideology of appropriate female behaviour that emphasizes chastity, obedience and. Patrifocality is centrally concerned with female sexual purity and family responsibility where women are prohibited from having prolonged contact with unrelated men, engaging in travel without a proper male escort, exercising authority in household decisions, or maintaining a residence separate from their families.

Banerjee and Mittar (1998) report that women are the first to lose jobs since they tend to do simple mechanical tasks which machines can easily replace. Women have the reputation of being inflexible carriers of tradition, but this position is actually due to underlying patriarchal relations, their education is normally such that they learn only to do A and B, not why A and B.

Jane E. Fountain (2000) in her study "Constructing the Information Society: Women, Information Technology, and Design" states that the human capital requirements of the Information Society demonstrate the need for women to strengthen their participation as experts, owners and designers of information technologies. This paper argues that stronger representation by women in technical roles not only would help to redress a troubling human capital deficit, but is highly likely to modify and expand the range of techno-logical applications, products, standards and practices to benefit all of society. She says, based on the unanticipated and 
strong societal impact women have had on other disciplines, that stronger representation of women in information technology will have a deep influence on technology outcomes and processes.

Ranjana Agarwal (2000), there are several employment opportunities in IT for young women who have had education and training in urban, English medium schools. The IT enabled services centers offer several opportunities to women. The IT enabled services require excellent verbal communication skills and pleasing personality. Data entry/data conversion needs typing conversion and strong written English communication skills. Apart from direct employment, ICT has benefited women in a number of ways. It is a viable tool of information and communication which goes a long way in empowerment of women. Immense amount of information is obtained through the internet. The number of IT users as well as IT professionals has been increasing over the years. The number of Internet users has been rising over the years. Women are expected to emerge as a large segment on the internet in the next 20 years. Effective and efficient use of information technology like internet can help in assimilating information about variety, range and quality of products, publicity and marketing of products and services. Apart from being used as a tool of information and communication and employment, application of ICT has created avenues for women empowerment. Of course, the single most important factor for increasing the ability of girls and women to take advantage of IT opportunities is education. This requires interventions at all levels, from literacy through scientific and technological education. To prepare women to enter IT fields, the concentrated efforts of the past 10 years to ensure access to quality basic education for girls should be continued and strengthened, with IT integrated into the programs. Indeed, improving the quality and reach of basic education through IT is increasingly essential to mitigating the gender divide for women in developing countries.

Huyer S and Sikoska T (2003), in their study "Overcoming the Gender Digital divide: Understanding ICT's and their potential for the Empowerment of Women" explores the leading approaches to maximizing the potential of ICTs for women's empowerment, examines the social context of technology, and identifies the main structural barriers and empower women through ICTs. Information and Communication Technologies have so far been predominantly designed and created within male-dominated environments and that the policies are usually formulated by male policy-makers has contributed to the gender digital divide. Yet it is maintained that Information Technology hold great potential for women's empowerment on an individual level (better selfesteem, increased confidence and more carrier opportunities) as well as on a collective level (improving their advocacy, lobbying and networking activities).

Patel and Parmentier (2005) argues that Women, of course, are working in the IT sector in India, both in the highly publicized IT-enabled call centers, as well as in the higher-skilled areas of IT production.

Anderson and Shrum (2006) conducted a study titled "Circumvention and Social Change". This study draws on ten years of work in south India to develop an interpretation of empowerment based on the concept of circumvention. It examines the social implications of a specific relationship between gender inequity and information and communication technologies (ICTs) under conditions of patrifocality that characterize the Indian subcontinent. Research in Kerala allowed them to witness the development and manifestation of this latent social change caused by the diffusion of ICTs. Qualitative interviews with women in IT revealed a change in the awareness of resources previously beyond their reach. Despite the fact that the local orientation of their careers persisted in terms of both educational and job related travel, they had begun to speak of more foreign contacts, foreign journals and international research opportunities in which they would like to participate by themselves, these findings evidence a social shift. Kerala families, with their near obsessive concern with education, began to acquire dial up internet connections at home. Regardless of the reason, women's domestic responsibilities were suddenly Focusing on Kerala Women and their overall status.

Mohanan Pillai \& Shanta (2008) argues while there are hundreds of government projects aimed at poverty alleviation, stock taking of their impact revealed that their outcomes have been mixed. In this context the newly designed projects based on IT specifically aimed at reducing the social, gender and economic divide needs to be examined to understand the lessons that these new initiatives offer. Such an attempt is made in this project on employment generating potential of this technology among poor women.

BL Centre for Development Research and Action (2009), in a study titled, Micro Finance and Empower ment of Scheduled Caste Women: An Impact Study of SHGs in Uttar Pradesh and Uttaranchal found out that $\mathrm{SHG}^{\mathrm{ee}} \mathrm{s}$ can contribute to overcome exploitation, create confidence for the economic self-reliance of the rural poor, particularly among women who are mostly invisible in the social structure.

Dhanya M.B and Sivakumar P (2010) The study was based on both primary and secondary data. The study confined to comparative analysis of economic condition of the study group in pre-Kudumbashree and post- Kudumbashree period. The major findings of the study are

1. Income from Kudumbashree units accounted a significant portion of the family income.

2. Major cause for increase in family income is due to the earning of other family members from various sources. 
3. Kudumbashree programme enabled the beneficiaries in overcoming the fear of authority, confidence in one's abilities, dimension of motivation, autonomy in the use of resources in households and participation in decisionmaking in the households.

4. Many Kudumbashree members are unaware of the capital invested in their organisation.

Manoj P. K (2012) has pointed out the high women empowerment potential of micro enterprises under Kudumbasree based on empirical evidence. Based on the findings of the study, the author has made suggestions for further improvement in the performance of the microenterprises under Kudumbasree and hence better level of the empowerment of women entrepreneurs of such micro enterprises.

In this area, the researcher has reviewed several studies on women in Information Technology industry, their empowerment, agency and the social change initiated by them, the gender issues faced by them in family as well as in career and the impact created on it by their empowerment and agency, national and state policies addressing gender issues in IT along with studies held among women IT professionals employed in various companies in Kerala.

\section{Objectives Of The Study}

1. To study about the accessibility of information technology among rural women in Kerala for Empowerment. 2. To evaluate the effectiveness of IT programs and identify the problems related with it implementation all over Kerala for rural women.

\section{Conceptual framework}

\section{Methodology}

While designing methodology the study objectives, as specified in the Research Proposal titled "Empowerment of Rural Women through Information Technology in Kerala" were strictly followed. For the selection of the sample, multistage sample frame work was used. The state of Kerala was divided into three zones namely northern, central and southern. From each zone one district i.e., from northern Wayanad, from central Ernakulam and from southern Idukki districts was selected at random. From each district two panchayats ie, Ambalawayal and Pulpally from Wayanad, Marady and Elamkunnapuzha from Ernakulam, Santhanpara and Muttom from Idukki was selected on a random basis. Thus the sample constitutes three districts and six panchayats. From each panchayat 40 respondents was selected and the sample size constitutes 240 respondents. Stratified random sampling method was used for the selection of respondents. For the purpose of this study the areas were selected randomly to identify the women folks as respondents. The women includes: working women's like school teachers, College teachers, Factory workers, Students, house wife who have exposure in information and communication technology and work as part time, Women employees who work in the area of information technology in government and private organizations, members of self-help group (SHGs), Kudumbasree who also has exposure in the field of information technology and communication.

\section{Primary data}

The primary data was collected using structured questionnaire. The questionnaire includes all aspects of socio-economic background of the respondent, their education, trading, income generation activities, constraints, benefits etc.

\section{Secondary data}

Besides primary data, secondary data were collected from the various IT initiatives of Government and private agencies for promoting women participation in ICT based services and jobs. The information about different schemes related to ICTs were also collected from Kerala Women's Commission, publications of various agencies like the Centre for Development Studies(CDS, Research works, studies conducted by institutions in other states, various journals, books and publications.

\section{Data analysis}

After the data collected from the field, it was processed in computer through the use of Statistical Package for Social Science (SPSS), excel, word and other software packages. Simple percentage was used for the analysis of processed data.

\section{Information Technology And Women Empowerment \\ ICT-new opportunities and new jobs for women \\ Revolutionary changes in IC T have been reinforcing economic and social changes, which in turn have been transforming the business and the society. There are different views on the involvement of developing countries in the ICT revolution. According to Avgerou, developing countries are}


usually seen as problematic hosts of information and communication technologies. Not only do most developing regions lack economic resources and indigenous techno-scientific capabilities to develop and deploy modern information system infrastructures, but they also tend not to make the best use of the opportunities of technology transfer. Comparisons with advanced economies show poor exploitation of the ICT in developing countries.

The participation of developing countries in the production of information technology (as opposed to the use of information technology in other industries) poses significant opportunities and challenges. IT industries are likely to constitute the largest industrial sub-sector. The ICT effects on employment pattern are complex and shifting. It has been observed that because of lower wages, developing countries gain skilled job.

ICT will affect employment pattern all over the world mainly in three ways: 1) As an industry, it creates new jobs in various companies; 2) It will change the pattern and level of employment in other industries, which are using ICT for competitive advantage; 3 ) It will create opportunity for creating new economic activity. The UN commission on status of women commented that women who constitute half of world's population, performs two third of world's work, receive one tenth of its income and owns less than hundredth of its property. Women represent three-quarters of heads of households in developing nations and for every one woman in poverty there are four dependent children. According to DATA and Statistics report, women are the poorest of the world's poor, representing 70 percent of the 1.3 billion people who live in absolute poverty (Data and Statistics, 2001). Nearly 900 million women have incomes of less than one dollar per day (UNESCO, 2001).

The International Labor Organization's analysis of employment trends shows that in spite of progress in some areas, women generally continue to earn lower incomes- suffer higher unemployment and remain largely restricted to low skilled part-time, informal, and unstable jobs (ILO, 2001). The ILO's World Employment report 2001 "life at work in the information economy" suggests that the development of ICT offers many new opportunities for women. But unless these are supported by deliberate policies to ensure participation, ownership, education, and ICT training for women- as well as family friendly policies in information work place, the old gender bias will persist.

It is generally believed in India, that for getting an employment in ICT industry one needs to be an expert in computer. However, the fact is that a large number of young people, especially women who are matriculate or graduates in any discipline can get suitable remunerative job in ICT (Prasad. 2003). According to John Gage of Sun Microsystems, three fundamental changes in ICT are responsible for explosion in their use to promote economic development are plummeting cost, expanding access to network, and more powerful human to machine interfaces. These three changes will continue and accelerate. Consequently, ICT will permeate the poorest regions of the world over the next twenty years (John Gage, 2002). ICTs promise an endless stream of benefits through technologies that generate employment and economic growth link.

\section{ICT and Women Empowerment in Kerala}

Kerala is one of the federal states of India, having an area of $38,863 \mathrm{sq} . \mathrm{km}$ and a population of 31.8 million, out of which nearly 75 percent live in rural area. Kerala, known as "God's own Country" for its natural beauty, is one of the world's top tourist destinations as well; having been listed as one among world's 50 „must see places" of a life time (National Geographic Traveller, 1999). The state takes a proud position in the indices of human development measured in terms of life expectancy, education, and healthcare. The literacy in the state is 90.92 percent, male literacy being 94.20 percent and female literacy being 87.86 percent. According to the 2001 census report, the state occupies the foremost position in the country with respect to education, healthcare, and population control (Government of Kerala, 2005). The achievements in these sectors are comparable to some of the most developed countries in the world.

Notwithstanding all these positive attributes that the state possesses, it is equally true that the famed Kerala model of development ie is facing a crisis. The state's achievements in the social sector did not go hand in hand with its progress in material production sector. The crisis in production sector is manifested in the virtual stagnation of the agricultural sector, deplorably lower level of productivity of important crops, growing apathy among cultivators, structural decay of the industrial sector dominated by ailing traditional industries and overburdening of the fragile ecosystem. The development paradox of Kerala lies in its high social development not being matched by its economic performance. This imbalance is largely explained by Kerala's stagnant agricultural and low industrial development. The logical outcome of this pattern of growth, which has evolved in Kerala, is the mounting unemployment in the state.

The state of Kerala has the highest incidence of unemployment in the country (Government of Kerala, 2005). It needs to be emphasized, however, that while general unemployment can largely be overcome through achievement of adequate growth of the economy, unemployment of the educated is not solved through higher rate of economic growth alone, although it is a necessary condition. 


\section{The ICT environment in Kerala}

The ICT revolution in developed countries was viewed with suspicion by the trade unions as well as the people of Kerala, for more than a decade because they considered it relevant only in rich countries that have shortage of manpower. The trade unions were against any positive action for encouragement and promotion of this technology. They feared that computerization would ultimately lead to destruction of job opportunities, which will be fatal for a state like Kerala, where unemployment is the main problem. They believed that the benefits of ICT would remain confined to the higher classes of the society. Consequently, the government did shy away from the promotion of ICT, even when intensive promotional activities were going on in neighbouring states like Karnataka, Andhra Pradesh and Tamil Nadu.

It took some time for the state to realize that the ICT is relevant to all the countries, irrespective of their level of economic development or varied local problems. Before 1995, the Government of Kerala did not make any serious attempt for the promotion of ICT. However, the growth of ICT in nearby states and all over the world, along with the lucrative jobs obtained by Keralites in ICT outside the state were eye- openers and the potential of ICT in creating large scale employment was realized by the state, albeit a little late (K.G.K. Nair, and Prasad, 2002). Though the government had initiated some activities in early nineties, it was only in 1998, that the government formulated a comprehensive IT policy, with a view to step up ICT promotion activities (Prasad, 2003). The IT policy was revised in the year 2001, incorporating many new features, with a view to increase the employment opportunities through the application of ICT.

The opportunity question for women entrepreneurs in the programmes and initiatives of the state in Kerala, the state is the main provider of ICT education, training and services. This is mainly done through the various programmes initiated by the Kerala State Information Technology Mission (KSITM) KSITM is the nodal agency for implementing the various programmes of the Department of Information Technology. The objectives of the KSITM include 'ICT dissemination to bridge the digital divide'. Accordingly, the Akshaya programme was initiated in 2002 to enable an expansion in citizens' ICT use, in Kerala. The programme has evolved from its initial emphasis on e-literacy and has come to take on a variety of government to citizen services. The officials of the programmes holding different portfolios were interviewed for the purpose of the research. Additionally, women engaged in the IT units of Kudumbashree also form a key part of the universe of women entrepreneurs in Kerala. (Kudumbashree is the poverty alleviation programme of the state government of Kerala where women's micro-enterprises are used as the main strategy for both poverty eradication and women's empowerment.

In Kerala, the responses to women's location in the whole ICT ecology of the state were invariably fore grounded by comments on the position of women in Kerala. According to the Director of the Akshaya programme, "women in Kerala have been have been much more advanced than women in the rest of the country" and that "Kerala women enjoy an equal status with the men". Moreover, Kerala has been a society which has historically taken up causes of marginalised segments of society like the lower castes, tribes, and women."

The Women Development Corporation (WDC) representatives also concurred with view that women were largely absent from public spaces, In Kerala parents are not ready to let women engage in the public domain. That is the main challenge that we face in getting women to participate in our programmes. Though the government gives certain advantages to the women, the parents are reluctant because they fear harassment at time of marriage. This, somewhat paradoxical, social status of women marked the Kerala landscape in which ICTs were introduced. Women were seen as suitable for the IT industry in many ways. Women are the ideal workers for the IT industry in Kerala since "the attrition rate is lower amongst women and they are more committed to work. The likelihood of getting organised and creating difficulties is also less in case of women." The IT industry in Kerala had come to employ women, who are 'equally if not more educated than men on an average in Kerala' Women have come to manage more than fifty percent of the Akshaya centres, and the IT units of Kudumbashree are solely run

by women. Additionally, some women (like the poorer fisher women) have encountered ICTs in the various extension programmes of the government. ICTs had subtly changed gender norms regarding work. It was with the coming of the IT industry that 'industries or companies were allowed to function beyond 10 to 5 kind of hours and women were permitted to work around the clock'. It was felt that with the opening of IT Parks, which have been planned in order to decentralise the IT industry, and Kudumbini, a 'household BPO concept', more and more women would be encouraged to work. The Consultant to the e-krishi programme pointed out the commercial opportunities for women in the programme. Aggregation of produce from different farmers and their online trading is one of the components of the e-krishi programme.

\section{Data Analysis}

The study is carried out in six panchayat of three districts of Kerala. The areas selected for the study were taken keeping in mind their location, access to ICT, population and literacy. All the respondents are women 
which includes school teachers, college teachers, factory workers, students, house wife who have exposure in information and communication technology, members of SHGs, Kudumbasree etc.

Table: 1 Availability of Proper Facility of ICT in Your Locality

\begin{tabular}{|c|c|c|c|c|c|c|c|c|c|c|c|}
\hline \multirow{2}{*}{ Location } & \multicolumn{2}{|c|}{ Strongly Agree 1} & \multicolumn{2}{|c|}{$\begin{array}{c}\text { Somevhat agree } \\
2\end{array}$} & \multicolumn{2}{|c|}{$\begin{array}{c}\text { Do not } \\
\text { Know } \\
3\end{array}$} & \multicolumn{2}{|c|}{$\begin{array}{l}\text { Disagree } \\
\quad 4\end{array}$} & \multicolumn{2}{|c|}{$\begin{array}{c}\text { Can't say } \\
5\end{array}$} & \multirow{2}{*}{ Total } \\
\hline & F & $\%$ & F & $\%$ & F & $\%$ & $F$ & $\%$ & F & $\%$ & \\
\hline Ambalavayal & 21 & 54 & 16 & 40 & 1 & 2 & 1 & 2 & 1 & 2 & 40 \\
\hline Pulpally & 26 & 67 & 11 & $\begin{array}{l}2 \\
6 \\
\end{array}$ & 1 & 2 & 0 & 0 & 2 & 5 & 40 \\
\hline Marady & 20 & 50 & 14 & \begin{tabular}{|l}
3 \\
5 \\
\end{tabular} & 2 & 5 & 0 & 0 & 4 & 10 & 40 \\
\hline Elamburnapuzha & 24 & 60 & 12 & 30 & 2 & 5 & 0 & 0 & 2 & 5 & 40 \\
\hline Santharpara & 22 & 55 & 13 & 33 & 3 & 8 & 1 & 2 & 1 & 2 & 40 \\
\hline Muttom & 22 & 55 & 13 & 33 & 2 & 5 & 2 & 5 & 1 & 2 & 40 \\
\hline Total & 135 & 56 & 79 & 33 & 11 & 5 & 4 & 1 & 11 & 5 & 240 \\
\hline
\end{tabular}

Source - Field Survey

There are lot of IT related initiatives and programmes reached to almost all sections and areas in Kerala. The above table shows that $44 \%$ of the total respondents of which the highest of Ambalavayal Panchayath $(48 \%)$ strongly agree with the availability of ICT facilities in their locality followed by $39 \%$ said IT is available easily and $8 \%$ and $5 \%$ respectively said they do not know or can't say about IT availability and only $4 \%$ disagree with the IT availability. In Marady Panchayath, no one is disagreeing with the availability of IT facilities in their locality.

Table: 2 Best source of getting information

\begin{tabular}{|c|c|c|c|c|c|c|c|c|c|c|c|}
\hline \multirow{2}{*}{ Location } & \multicolumn{2}{|c|}{ TV 1} & \multicolumn{2}{|c|}{$\begin{array}{c}\text { Internet } \\
2\end{array}$} & \multicolumn{2}{|c|}{$\begin{array}{c}\text { Prirt Media } \\
3\end{array}$} & \multicolumn{2}{|r|}{$\begin{array}{l}\text { Radio } \\
4\end{array}$} & \multicolumn{2}{|c|}{$\begin{array}{c}\text { Any other } \\
5\end{array}$} & \multirow{2}{*}{ Total } \\
\hline & F & $\%$ & F & $\%$ & F & $\%$ & F & $\%$ & F & $\%$ & \\
\hline Ambalavayal & 24 & 60 & 5 & 13 & 2 & 5 & 7 & 18 & 2 & 5 & 40 \\
\hline Pulpally & 18 & 45 & 16 & $\begin{array}{l}3 \\
9\end{array}$ & 4 & 10 & 2 & 5 & 0 & 0 & 40 \\
\hline Marady & 12 & 30 & 9 & $\begin{array}{l}2 \\
3\end{array}$ & $\begin{array}{l}1 \\
6\end{array}$ & 39 & 3 & 7 & 0 & 0 & 40 \\
\hline Elamkurnapuzha & 26 & 65 & 7 & 18 & 4 & 10 & 3 & 7 & 0 & 0 & 40 \\
\hline Santhanpara & 22 & 55 & 6 & 15 & 9 & 23 & 2 & 5 & 1 & 3 & 40 \\
\hline Muttom & 21 & 53 & 8 & 20 & 7 & 18 & 2 & 5 & 2 & 5 & 40 \\
\hline Total & 123 & 51 & 51 & 21 & 42 & 18 & 19 & 8 & 5 & 2 & 240 \\
\hline
\end{tabular}

Source - Field Survey

People gets information from various sources, from the above table it is clear that $51 \%$ of the total respondents get information from TV media followed by $21 \%$ and $18 \%$ gets information from internet and Print Medias respectively and $5 \%$ depend on some other sources.

Table: 3 Introduction of Internet made to get information easily

\begin{tabular}{|c|c|c|c|c|c|c|c|c|c|c|c|}
\hline \multirow[t]{2}{*}{ Location } & \multicolumn{2}{|c|}{ Strondy Aaree 1} & \multicolumn{2}{|c|}{$\begin{array}{l}\text { Somevhat agree } \\
2\end{array}$} & \multicolumn{3}{|c|}{$\begin{array}{c}\text { Donot knav } \\
3\end{array}$} & $\frac{\text { Di gagree }}{4}$ & \multicolumn{2}{|c|}{$\begin{array}{c}\text { Car't say } \\
5\end{array}$} & \multirow[t]{2}{*}{ Total } \\
\hline & $F$ & $\%$ & F & $\%$ & F & $\%$ & F & $\%$ & F & $\%$ & \\
\hline Ambalavayal & 16 & 40 & 16 & 40 & 3 & 7 & 1 & 3 & 4 & 10 & 40 \\
\hline Pulpally & 21 & 53 & 12 & 3 & 3 & 7 & 2 & 5 & 2 & 5 & 40 \\
\hline Marady & 14 & 35 & 24 & $\begin{array}{l}6 \\
n\end{array}$ & 0 & 0 & 0 & lo & 2 & 5 & 40 \\
\hline Elamkunnapuzha & 17 & 43 & 20 & 50 & 1 & 3 & 1 & 3 & 1 & 3 & 40 \\
\hline Santhanpara & 22 & 55 & 16 & 40 & 0 & 0 & 1 & 3 & 1 & 3 & 40 \\
\hline Muttom & 18 & 45 & 17 & 43 & 1 & 3 & 1 & 3 & 3 & 7 & 40 \\
\hline Total & 108 & 45 & 105 & 44 & 8 & 3 & 6 & 3 & 13 & 5 & 240 \\
\hline
\end{tabular}

Source - Field Survey 
The above table shows that the use of internet is made the easy access of information because $45 \%$ of the total respondents strongly agree that internet made to get information easily and near $44 \%$ also somewhat agreed with this. Total respondents of 3\% and 5\% do not know and can't say about this and 3\% disagree with this argument.

Table: 4 Easy Accesses to Internet

\begin{tabular}{|c|c|c|c|c|c|}
\hline \multirow{2}{*}{ Location } & \multicolumn{2}{|c|}{ Yes } & \multicolumn{2}{|c|}{ No } & \multirow{2}{*}{ Total } \\
\hline & $\mathrm{F}$ & $\%$ & $\mathrm{~F}$ & $\%$ & \\
\hline Ambalavayal & 27 & 68 & 13 & 32 & 40 \\
\hline Pulpally & 33 & 83 & 7 & 17 & 40 \\
\hline Marady & 36 & 90 & 4 & 10 & 40 \\
\hline Elamkunnapuzha & 30 & 75 & 10 & 25 & 40 \\
\hline Santhanpara & 28 & 70 & 12 & 30 & 40 \\
\hline Muttom & 31 & 78 & 9 & 22 & 40 \\
\hline Total & 185 & 77 & 55 & 23 & 240 \\
\hline
\end{tabular}

Source - Field Survey

From the above table it is clear that women also have easy access to internet in their area because $77 \%$ of the respondents said the answer yes to the question easy access to internet and 23\% said no. In Marady and Pulpally Panchayath have the maximum number of internet users.

Table: 5 Sources of Access

\begin{tabular}{|c|c|c|c|c|c|c|c|c|c|}
\hline \multirow{2}{*}{ Location } & \multicolumn{2}{|c|}{ Home } & \multicolumn{2}{|c|}{ Office } & \multicolumn{2}{|c|}{ Cyber cafe } & \multicolumn{2}{|c|}{ Any other } & \multirow{2}{*}{ Total } \\
\hline & $\mathrm{F}$ & $\%$ & $\mathrm{~F}$ & $\%$ & $\mathrm{~F}$ & $\%$ & $\mathrm{~F}$ & $\%$ & \\
\hline Ambalavayal & 4 & 15 & 9 & 35 & 10 & 38 & 3 & 12 & 26 \\
\hline Pulpally & 9 & 28 & 9 & 28 & 13 & 41 & 1 & 3 & 32 \\
\hline Marady & 7 & 19 & 11 & 30 & 16 & 44 & 2 & 5 & 36 \\
\hline Elamkunnapuzha & 4 & 14 & 8 & 28 & 14 & 50 & 2 & 7 & 28 \\
\hline Santhanpara & 6 & 21 & 8 & 28 & 13 & 45 & 2 & 7 & 29 \\
\hline Muttom & 8 & 21 & 12 & 31 & 17 & 43 & 2 & 5 & 39 \\
\hline Total & 38 & 20 & 57 & 30 & 83 & 44 & 12 & 6 & 190 \\
\hline
\end{tabular}

Source - Field Survey

From the above table it is found that $44 \%$ of the total respondents of which the highest from Elamkunnapuzha said, Cyber café is the best source of access to internet followed by $30 \%$ get access in their offices for their official and personal use about $20 \%$ of the respondents have internet facility in their home and $6 \%$ depends some other sources for their internet access.

Table: 6

Facility of Cable Television

\begin{tabular}{|c|c|c|c|c|c|}
\hline \multirow{2}{*}{ Location } & \multicolumn{2}{|c|}{ Yes } & \multicolumn{2}{|c|}{ No } & \multirow{2}{*}{ Total } \\
\hline & $\mathrm{F}$ & $\%$ & $\mathrm{~F}$ & $\%$ & \\
\hline Ambalavayal & 38 & 95 & 2 & 5 & 40 \\
\hline Pulpally & 34 & 85 & 6 & 15 & 40 \\
\hline Marady & 33 & 82 & 7 & 18 & 40 \\
\hline Elamkunnapuzha & 31 & 77 & 9 & 23 & 40 \\
\hline Santhanpara & 27 & 68 & 13 & 32 & 40 \\
\hline Muttom & 33 & 83 & 7 & 17 & 40 \\
\hline Total & 196 & 82 & 44 & 18 & 240 \\
\hline
\end{tabular}

\section{Source - Field Survey}

There is also easy availability of Cable Television in the state of Kerala. From the above table it is found that $82 \%$ of the total respondents said they have the facility of Cable Television and $18 \%$ said they have no access to Cable Television. In Ambalavayal panchayath 95\% of the respondents have Cable TV access. 
Table: 7 Training or exposure in the field of Computer

\begin{tabular}{|c|c|c|c|c|c|}
\hline \multirow{2}{*}{ Location } & \multicolumn{2}{|c|}{$\mathrm{Yes}$} & \multicolumn{2}{|c|}{ No } & \multirow{2}{*}{ Total } \\
\hline & F & $\%$ & F & $\%$ & \\
\hline Ambalavayal & 28 & 70 & 12 & 30 & 40 \\
\hline Pulpally & 30 & 75 & 10 & 25 & 40 \\
\hline Marady & 32 & 80 & 8 & 20 & 40 \\
\hline El amkurnapuzha & 34 & 85 & 6 & 15 & 40 \\
\hline Santhanpara & 33 & 83 & 7 & 17 & 40 \\
\hline Muttom & 32 & 80 & 8 & 20 & 40 \\
\hline Total & 189 & 79 & 51 & 21 & 240 \\
\hline
\end{tabular}

\section{Source - Field Survey}

There is also exposure to the women in the field of computer or computer training. Most of them are familiar in the use of computer. They have got exposure either through computer training or by trying themselves. 189 respondents said they are used to computer or computer related activities. It is necessary for their daily use either of office job or of personal work. 51 said either they have not got computer training or not exposed to the use of computer, most of the respondents are from Emakunnapuzha panchayath $85 \%$ i.e. 34 of 40 respondents.

Table: 8

Nature of Computer Training

\begin{tabular}{|c|c|c|c|c|c|c|c|}
\hline \multirow{2}{*}{ Location } & \multicolumn{2}{|c|}{ Formal } & \multicolumn{2}{|c|}{ Informal } & \multicolumn{2}{|c|}{ Not Applicable } & \multirow{2}{*}{ Total } \\
\hline & $\mathrm{F}$ & $\%$ & F & $\%$ & F & $\%$ & \\
\hline Ambalavayal & 20 & 50 & 11 & 28 & 9 & 23 & 40 \\
\hline Pulpally & 21 & 53 & 7 & 18 & 12 & 30 & 40 \\
\hline Marady & 31 & 77 & 6 & 15 & 3 & 7 & 40 \\
\hline Elamkunnapuzha & 22 & 55 & 14 & 35 & 4 & 10 & 40 \\
\hline Santhanpara & 25 & 63 & 12 & 30 & 3 & 7 & 40 \\
\hline Muttom & 24 & 60 & 8 & 20 & 8 & 20 & 40 \\
\hline Total & 143 & 60 & 58 & 24 & 39 & 16 & 240 \\
\hline
\end{tabular}

\section{Source - Field Survey}

In Kerala, there are lot of computer training centres in the government and private sector. Out of the total respondents, $60 \%$ got formal computer training in their locality and $24 \%$ have got informal training. From the above table it is clear that Ernakulam district have the large number of computer training centres. It is also found that $16 \%$ of the total respondents have not getting any type of computer training. 
Table: 9 Government is giving sufficient support to provide ICT education to the women in your area

\begin{tabular}{|c|c|c|c|c|c|c|c|c|c|c|c|}
\hline \multirow[t]{2}{*}{ Location } & \multicolumn{2}{|c|}{ Strongly Agree 1} & \multicolumn{2}{|c|}{$\begin{array}{c}\text { Somewhat agree } \\
2\end{array}$} & \multicolumn{2}{|c|}{$\begin{array}{c}\text { Do not know } \\
3\end{array}$} & \multicolumn{2}{|c|}{$\begin{array}{c}\text { Disagree } \\
4\end{array}$} & \multicolumn{2}{|c|}{$\begin{array}{c}\text { Can't say } \\
5\end{array}$} & \multirow[t]{2}{*}{ Total } \\
\hline & $\mathrm{F}$ & $\%$ & $\mathrm{~F}$ & $\%$ & $\mathrm{~F}$ & $\%$ & $\mathrm{~F}$ & $\%$ & $\mathrm{~F}$ & $\%$ & \\
\hline Pulpally & 9 & 23 & 14 & 35 & 4 & 10 & 10 & 25 & 3 & 7 & 40 \\
\hline Marady & 10 & 25 & 22 & 55 & 4 & 10 & 2 & 5 & 2 & 5 & 40 \\
\hline Elamkunnapuzha & 13 & 33 & 7 & 18 & 8 & 20 & 3 & 7 & 9 & 23 & 40 \\
\hline Muttom & 11 & 28 & 13 & 33 & 6 & 15 & 5 & 13 & 5 & 13 & 40 \\
\hline Total & 68 & 28 & 79 & 33 & 37 & 15 & 30 & 13 & 26 & 11 & 240 \\
\hline
\end{tabular}

Source - Field Survey

When the researcher asked about the fund allocation from central and state government for providing ICT educations in their locality only $28 \%$ of the total respondents strongly agree with this and $33 \%$ of the total respondents said to certain extend, they agreed with government support. $15 \%$ and $13 \%$ are of the opinion that they do not know about government support and disagree with government assistance for ICT education. At the same time $11 \%$ have no response to this matter.

TABLE: 10 Entry of women workforce in ICT industry is affected by their Socio- economic and educational development

\begin{tabular}{|c|c|c|c|c|c|c|c|c|c|c|c|}
\hline \multirow[t]{2}{*}{ Location } & \multicolumn{2}{|c|}{ Strongly Agree 1} & \multicolumn{2}{|c|}{$\begin{array}{c}\text { Somevhat agree } \\
2\end{array}$} & \multicolumn{2}{|c|}{$\begin{array}{c}\text { Do nat know } \\
3\end{array}$} & \multicolumn{2}{|c|}{$\begin{array}{c}\text { Disagree } \\
4\end{array}$} & \multicolumn{2}{|c|}{$\begin{array}{c}\text { Can't say } \\
5\end{array}$} & \multirow[t]{2}{*}{ Total } \\
\hline & $F$ & $\%$ & $F$ & $\%$ & $F$ & $\%$ & F & $\%$ & $F$ & $\%$ & \\
\hline Ambalavayal & 13 & 33 & 18 & 45 & 5 & 13 & 3 & 7 & 1 & 3 & 40 \\
\hline Pulpally & 12 & 30 & 15 & 38 & 3 & 7 & 6 & 15 & 4 & 10 & 40 \\
\hline Marady & 14 & 35 & 14 & 35 & 10 & 25 & 1 & 3 & 1 & 3 & 40 \\
\hline Elamkunnapuzha & 17 & 43 & 15 & 38 & 6 & 15 & 1 & 3 & 1 & 3 & 40 \\
\hline S anthanpara & 19 & 48 & 16 & 40 & 3 & 7 & 1 & 3 & 1 & 3 & 40 \\
\hline Muttom & 15 & 38 & 16 & 40 & 5 & 13 & 2 & 5 & 2 & 5 & 40 \\
\hline Total & 90 & 38 & 94 & 39 & 32 & 13 & 14 & 6 & 10 & 4 & 240 \\
\hline
\end{tabular}

Source - Field Survey

In Kerala there are number of avenues for entry of women in to ICT industry. This is helpful for the women's socio- economic and academic development. From the above table it is clear that more than half of the total respondents i.e. $38 \%$ and $39 \%$ strongly agree and somewhat agree with this. Out of total respondents only $6 \%$ disagree with this. At the same time $13 \%$ do not know and $4 \%$ can't say about this.

\section{Findings}

1. In Kerala a substantial number of women has stepped in to the Information Technology sector and enjoyed the fruits of the system. From the study it is clear that, when asked about ICT made life easier, more than half of the respondents are agreed with this fact.

2. There are lot of IT related initiatives and programmes introduced by the Central and state government for women empowerment but not reached to all sections and areas in Kerala.

3. Internet and Cable Television are the two popular medium of ICT infrastructure in Kerala.

4. A total of $81 \%$ of the respondents said IT is an essential device for today's job environment.

5. Most of the women's depends cyber cafe for their information and communication needs.

6. Major respondent's demands computer training for their ICT needs but only $60 \%$ gets formal training from institutions.

7. Fund allocation from government is not sufficient to make support for IT infrastructure in rural area for women.

8. More than half the women respondents agree that the use of ICT helps their socio-economic and educational developments. 


\section{Suggestions}

1. The government should take more steps to reach the ICT related programmes to all sections of rural areas for women empowerment.

2. Most of the rural women depends cyber cafe for their ICT needs. The government should make arrangements to install computers and internet connections for deserving women's in their homes and nearby institutions like Kudumbasree units etc.

3. The government should take initiatives for starting more training centres in rural areas for computer training of women employees, entrepreneurs and for students.

4. The government should take steps to invest more funds for computer education in rural areas for women.

5. There is a disparity in urban and rural areas regarding the enjoyment of ICT benefits. The government and other local authorities should take steps to make a balanced arrangement for this.

\section{Conclusion}

It is true that technology is one of the developmental tools. At the same time the new technological inventions have to be properly implemented and people trained to utilize its advancement for their development. This study identifies accessibility of ICT to rural women how it promote gender equality and the empowerment of women. The role of information technology for women's empowerment acquires greatest significance yet it requires highly sophisticated and learned society as a basic ground. Close observation of the scenario in India indicates that the state like Andhra Pradesh, Kerala, Tamil Nadu and Maharashtra are marching ahead in the field of ICT because of high female literacy level. It can be concluded that the women of Kerala is empowered through the help of information and communication technology. The government of Kerala has also taken several steps and implemented various plans and policies along with government of India bring the rural women into the IT related industry. Various organisations, private parties have also extended their help to promote IT among the rural women. The social and economic barriers could be effectively overcome through various ICT programmes. ICT has made an impression in the digital divide and in scripted the opening of opening up the opportunities of the information, communication and technology to the poor and socially rearward women. Governments and other actors should promote an active and visible policy for ICT based sustainable women empowerment in Kerala.

\section{References}

\section{Journal papers}

[1]. Annual Report of Human Resource Development, Government of India, 2011-12

[2]. Annual Report of Human Resource Development, Government of India, 2012-13

[3]. Anju M, Sidney RS (2002). Measuring Women's Empowerment as a Variable in International Development, World Bank Workshop on Poverty and Gender: New Perspectives pp.10-50.

[4]. Eswar R, Patnaik B (2006). "Empowerment of Women in Orissa: A Case Study of Koraput District", Women Empowerment, Panigrahy R.L, Dasarathi Bhuyan, Discovery Publishing House, New Delhi pp.43-56.

[5]. Dr. Chandrasekhar, K.S, Siva prakash (2010). The Role Of Information Communication Technology In Women Empowerment And Poverty Eradication In Kerala,APJRBAM 1(2) available at http://www.skirec.com

[6]. V.Suliman.et.al (2011). ICT and empowerment of Indian rural women available at www.crispindia.org.

[7]. Dr.Anjum.B, Tiwari.R (2012). Role of Information Technology in Women Empowerment, in EXCEL International Journal of Multidisciplinary Management studies 2(1) available at http://zenithresearch.org.in

[8]. Prasad.P.N, Sreedevi (2007). Economic Empowerment of women through Information Technology: A case study from an Indian state, in International journal of women studies 8(4), 107-120 available at http://vc.bridgew.edu/jiws/vol8/iss4/8.

[9]. Jayashree.K (2007). Empowerment of Women through Information and Communication Technologies: Observations from Village Knowledge Centers of Pudhucherry.

[10]. VAPS. Enhancing Women Empowerment through Information and Communication Technology- A Report.

[11]. N.Vikas(2001), Empowerment and governance through Information and communication Technologies: women's perspective, 33,317-339 available at http://www.idealibrary.com

[12]. K.Raman, K.Rajesh (2011), Information Technology Empowers by women, available at International Journal for Science and Emerging Technologies with latest tends 1(1), 1-5.

[13]. Dr.Arivanadan,M (2013), Socio-economic Empowerment FO Rural women through ICT in International Journal of Rural studies(IJRS) 20(2), 1-7available at http://www.vri-online.org.uk/ijrs

[14]. M.C.Minimol,Makesh(2012), Empowering Rural women in Kerala: A Study on the role of Self Help Groups (SHGs) in International Journal of Sociology and Anthropology 4(9) 270-280 available at

[15]. http://www.academicjournals.org/IJSA

[16]. Singh.M.P (2014), Girls' Education and Gender Equality in India in Women's Link 20 (1) 16-21.

Books

[17]. Dr.Sr K.D, Rosa (2010) Empowerment of Women - The impact of Employment Delhi Abhijeet Publications 2010.

[18]. Varghese, J (2012) Women Empowerment through Literacy Campaign New Delhi Concept Publishing Company Pvt.Ltd.2012.

[19]. Singh, B.N (2011) Economics of Women Education and Empowerment Delhi Abhijeet Publications 2011.

[20]. Mitra, J (1997) Women and Society - Equality and Empowerment New Delhi Kanishka Publishers, Distributors 2012.

[21]. Dr. Mohan (2012) Women Empowerment through Microfinance New Delhi Axis Books Pvt. Ltd. 2012.

[22]. Agrawal, M (2013) Women Empowerment and Gender Equality New Delhi Kanishka Publishers, Distributors 2013.

[23]. Dr.Makwana, R.H (2012) Women Empowerment through Panchayati Raj New Delhi ABD Publishers 2012.

[24]. Cauvery, R, Nayak, U.K, Girija, M, Meenakshi, R (2003) Research Methodology New Delhi S.Chand \& Company Pvt.Ltd.2010.

[25]. Gaur, A.S, Guar, S.S (2006) Statistical Methods for Practice and Research - A Guide to Data Analysis using SPSS New Delhi Sage Publications 2012. 